Katarina B. Putica

University of Belgrade

Innovative Centre of

the Faculty of Chemistry
УДК: 371.3::547

https://doi.org/10.18485/uzdanica.2020.17.2.18

Оригинални научни рад

Примљен: 31. август 2020.

Прихваћен: 30. новембоар 2020.

\title{
GRAMMAR SCHOOL STUDENTS' PERCEPTIONS TOWARD ORGANIC CHEMISTRY AND THE IMPLEMENTATION OF CONTEXT-BASED APPROACH IN ORGANIC CHEMISTRY TEACHING ${ }^{1}$
}

\begin{abstract}
Along with being an essential part of everyday life, organic chemistry has tremendous economic significance. Given that grammar school represents a stepping stone toward university education and professional carriers in this field, improving organic chemistry teaching at grammar school level is of great importance. Consequently, this research aimed to determine the way in which organic chemistry is typically taught in grammar school, grammar school students' perceptions toward organic chemistry and their perceptions concerning the potential of context-based teaching approach to facilitate organic chemistry learning. Data were obtained by means of the two questionnaires, completed by 163 third year grammar school students. It was concluded that organic chemistry teaching in grammar school primarily consists of the teacher's presentation of academic content, which is only occasionally linked to everyday life and previously acquired chemistry knowledge. At the same time, students perceive organic chemistry as abstract, difficult to understand and more difficult to learn than general and inorganic chemistry, while around $40 \%$ of students perceive the quality of their organic chemistry knowledge to be poor. Conversely, students perceive context-based organic chemistry lessons to be more interesting than their typical organic chemistry lessons and point out that such an approach to teaching could enhance their motivation to learn organic chemistry and their ability to apply organic chemistry knowledge in everyday life. Although they are not convinced that it could also improve their understanding of organic chemistry, nearly $60 \%$ of students recommend to their teachers more frequent application of context-based approach in organic chemistry teaching.
\end{abstract}

Keywords: organic chemistry, context-based teaching approach, grammar school students, questionnaires.

\footnotetext{
${ }^{1}$ This research was financed by the Ministry of Education, Science and Technological Development of the Republic of Serbia, contract number 451-03-68/2020-14/200288.
} 


\section{INTRODUCTION}

The range of application of organic compounds in everyday life is enormous and it includes products such as medicines, cosmetics, rubber and plastic products, detergents, fuels, coatings, as well as food. Consequently, organic chemistry is crucial to modern world economies (Nicolau 2014: 5). Given that grammar school represents a stepping stone toward university education and professional carriers in this field, providing timely interventions in order to help the grammar school students overcome any difficulties they are faced with while learning organic chemistry is of the utmost importance (O'Dwyer, Childs 2014: 988). Previous research studies found that the most prominent difficulties associated with organic chemistry learning are students' lack of motivation to learn organic chemistry (Johnstone 2006: 61), low conceptual understanding and unawareness of the importance of organic chemistry in everyday life (O'Dwyer, Childs 2014: 988).

One of the main causes of these difficulties could lie in the way in which organic chemistry is taught to students. More specifically, if organic chemistry teaching is reduced to teacher's presentation of pure academic content, the students will have little chance to develop the awareness of the relevance of that content in everyday life (O’Dwyer, Childs 2014: 990). Furthermore, being unaware of the relevance of a given content diminishes students' motivation and positive attitude toward learning. Given that positive attitude and motivation play an important role in its promotion this, in turn, represents a serious obstacle to meaningful learning (Novak 2010: 106). Additionally, if the way in which new knowledge is taught to students does not propel them to make significant connections between new information and previously acquired knowledge, rote memorization is likely to occur, and low levels of conceptual understanding have primarily been associated with rote memorization dominated learning (Bretz 2001: 1113).

\section{LITERATURE REVIEW ON CONTEXT-BASED TEACHING APPROACH}

Around the world, context-based approach has been recognized as one of the key teaching approaches for promoting students' conceptual understanding, motivation to learn natural sciences and the awareness of the relevance of scientific knowledge in everyday life (Bennett, Lubben, Hogarth 2007: 363). Within this approach, diverse contexts from everyday life are used as a framework for introducing new scientific knowledge to students. The use of contexts that the students find relevant for themselves and the society that they live in is essential for the promotion of their motivation to learn natural sciences and functionalization of scientific knowledge (Gilbert 2006: 964-965). 
In the field of natural sciences, two specific forms of context-based approach, known as the STS and SSI approaches, have been applied (Bennett, Lubben, Hogarth 2007: 347). The STS (Science Technology Society) approach is based on the use of cultural, economic, political as well as environmental contexts, as the basis for the introduction of new knowledge. The application of this approach is aimed at developing students' awareness of the impact of scientific and technological discoveries on modern society, as well as developing students' ability to anticipate and perceive the consequences of the application of these discoveries for themselves and society as a whole. The SSI (Socio-Scientific Issues) approach contains all the elements of the STS approach, but is more oriented towards developing students' awareness that the application of scientific and technological discoveries in contemporary society raises a number of ethical and moral issues.

When it comes to the implementation of context-based approach in chemistry teaching in high school, the results of previous research studies confirmed its potential to promote students' chemical literacy (Fensham 2009: 894), as well as students' motivation to learn inorganic chemistry (Kuhn, Muller 2014: 16). However, there is practically no research evidence concerning the grammar school students' perceptions toward the implementation of context-based approach in organic chemistry teaching.

\section{RESEARCH METHODOLOGY}

\section{RESEARCH AIMS}

This research had two aims. As discussed earlier, organic chemistry plays an important role in the modern society, but previous research reported difficulties with the conceptual understanding, low motivation to learn organic chemistry and unawareness of the relevance of organic chemistry in everyday life, which could all be caused by the way in which organic chemistry is taught to students. Since grammar school represents the foundation for university education and future professional carriers in this field, the first aim of this research was to determine the way in which organic chemistry is typically taught in grammar school, as well as grammar school students' perceptions toward organic chemistry. Given that context-based approach has been recognized as one of the key approaches for overcoming all the aforementioned difficulties, the second aim of this research was to explore grammar school students' perceptions toward its implementation in organic chemistry teaching. 


\section{RESEARCH DESIGN}

In accordance with the research aims, a survey within which students completed two questionnaires has been conducted. The general outlines of the research design are presented in Table 1.

Table 1. The research design

\begin{tabular}{cl}
\hline Lesson period number & Activities \\
\hline 1. & Students complete Questionnaire 1 \\
2. & Context-based elaboration of the teaching unit Alcohols \\
3. & Students complete Questionnaire 2 \\
\hline
\end{tabular}

\section{RESEARCH SAMPLE}

A total of 163 students (aged 17-18 years) from two grammar schools in Belgrade (four third-year natural sciences stream of study classes from each of the schools) completed the two questionnaires. The written consent for conducting the survey has been obtained from the director and science committee from each of the schools. All of the students in the research sample were volunteers.

\section{RESEARCH INSTRUMENTS}

Research data were collected by means of Questionnaire 1 and Questionnaire 2. The questions in Questionnaire 1 referred to students' perceptions toward what kind of activities comprise their typical organic chemistry lesson, their perceptions toward the complexity, abstractness and extensiveness of the organic chemistry curriculum and their perceptions toward the quality of organic chemistry knowledge that they acquired during the current school year. The questions in Questionnaire 2 examined students' views on beneficial effects that could be expected from the application of context-based approach in organic chemistry teaching.

\section{CONTEXT-BASED ELABORATION OF THE TEACHING UNIT ALCOHOLS}

In accordance with the principles of context-based teaching approach, within the elaboration of the teaching unit Alcohols, the nomenclature, as well as physical and chemical properties of these compounds, were elaborated within the examples of their application in everyday life.

Following the teachers' introductory presentation of the key structural properties of alcohols, as well as the rules for naming alcohols according to the IUPAC 
nomenclature, each student was presented with a context-based textual material about these compounds. Within this material, structural formulas, nomenclature, as well as the examples of the application of alcohols that are the most common in everyday life were presented. On the basis of this, students were supposed to answer the questions related to the structure, nomenclature and physical and chemical properties of alcohols, and, thus, acquire new knowledge about these compounds. The overview of examples from everyday life that the students used in order to answer these questions is presented in Table 2.

Table 2. Context-based elaboration of the teaching unit Alcohols

\begin{tabular}{|c|c|c|}
\hline Type of knowledge & Questions for students & $\begin{array}{l}\text { Examples from everyday life used to acquire } \\
\text { this type of knowledge }\end{array}$ \\
\hline Nomenclature of alcohols & $\begin{array}{l}\text { Ascertain IUPAC and trivial names } \\
\text { of the following alcohols }\end{array}$ & $\begin{array}{l}\text { Alcohol found in alcoholic beverages and } \\
\text { medicinal alcohol; alcohol which is a key } \\
\text { component of antifreeze; alcohol found in } \\
\text { hand creams }\end{array}$ \\
\hline $\begin{array}{l}\text { Structural properties of } \\
\text { alcohols }\end{array}$ & $\begin{array}{l}\text { Are there alcohols that contain } \\
\text { more than one hydroxyl group? }\end{array}$ & $\begin{array}{l}\text { Alcohol which is a key component of } \\
\text { antifreeze; alcohol found in hand creams }\end{array}$ \\
\hline \multirow[t]{3}{*}{$\begin{array}{l}\text { Physical properties of } \\
\text { alcohols }\end{array}$} & $\begin{array}{l}\text { Ascertain whe her ethanol is } \\
\text { soluble in water }\end{array}$ & $\begin{array}{l}\text { Alcoholic beverages as aqueous solutions of } \\
\text { ethanol }\end{array}$ \\
\hline & $\begin{array}{l}\text { Ascertain whe her ethanol is } \\
\text { soluble in non-polar solvents }\end{array}$ & $\begin{array}{l}\text { Behavioral changes associated with alcohol } \\
\text { intoxication, caused by ethanol's penetration } \\
\text { of the blood-brain barrier, whose key } \\
\text { components are phospholipid molecules }\end{array}$ \\
\hline & $\begin{array}{l}\text { Ascertain the key factors that } \\
\text { influence the boiling and freezing } \\
\text { points of alcohols }\end{array}$ & $\begin{array}{l}\text { Comparison of the boiling points of ethylene } \\
\text { glycol and ethanol; freezing-point depression } \\
\text { of water in the presence of antifreeze }\end{array}$ \\
\hline \multirow[t]{4}{*}{$\begin{array}{l}\text { Chemical properties of } \\
\text { alcohols }\end{array}$} & $\begin{array}{l}\text { What are the products of oxidation } \\
\text { of ethanol in the presence of } \\
\text { potassium dichromate? }\end{array}$ & Alcotest \\
\hline & $\begin{array}{l}\text { How would you distinguish } \\
\text { between primary, secondary and } \\
\text { tertiary alcohols? }\end{array}$ & $\begin{array}{l}\text { Addition of Lucas' reagent to medicinal } \\
\text { alcohol }\end{array}$ \\
\hline & Are alcohols combustible? & $\begin{array}{l}\text { Use of methanol and ethanol as fuels for } \\
\text { racing cars }\end{array}$ \\
\hline & $\begin{array}{l}\text { What are the reactants and } \\
\text { products of the reaction of } \\
\text { alcoholic fermentation? }\end{array}$ & $\begin{array}{l}\text { Ethanol as a renewable energy source which } \\
\text { can be obtained from sugar cane }\end{array}$ \\
\hline
\end{tabular}

\section{DATA ANALYSIS}

For the first question in Questionnaire 1 referring to students' perceptions toward what percentage of time is devoted to various activities during one of their typical organic chemistry lessons, the mean values calculated from all the percentages that the students enlisted for each activity are reported. For all the other 
questions in Questionnaire 1 and Questionnaire 2 the number and percentage of students who chose each of the options that were offered are provided.

\section{RESEARCH RESULTS}

\section{RESULTS OF QUESTIONNAIRE 1}

Students' perceptions concerning the percentage of time that is being devoted to various activities during one of their typical organic chemistry lessons are presented in Table 3.

Table 3. Activities that comprise a typical organic chemistry lesson

The teacher presents the academic content, according to the organic chemistry textbook

55,82

The teacher links the new organic chemistry knowledge with the previously acquired general and inorganic chemistry knowledge

As can be seen from Table 3, most of the time of a typical organic chemistry lesson is devoted to the teacher's presentation of academic content, according to the organic chemistry textbook. Some of the time is devoted to linking of the new knowledge with the previously acquired organic chemistry, as well as general and inorganic chemistry knowledge and everyday life, while performing organic chemistry experiments, either by the teacher or the students, occurs only on rare occasions.

Students' perceptions concerning the statement that organic chemistry is an abstract subject, weakly connected with everyday life, are presented in Table 4. 
Table 4. Students' perceptions toward the statement that organic chemistry is an abstract subject, weakly connected with everyday life

\begin{tabular}{lcc}
\hline Option & $f$ & $\%$ \\
\hline I completely agree & 51 & 31,29 \\
I partially agree & 44 & 26,99 \\
I do not agree & 68 & 41,72 \\
\hline
\end{tabular}

As can be seen in Table 4 , nearly $42 \%$ of the students do not agree with the statement that organic chemistry is abstract and weakly connected with everyday life. However, all the other students completely, or at least partially, agree with this statement.

Students' perceptions toward the statements that organic chemistry is more difficult to learn than general and inorganic chemistry, that its curriculum is too extensive and difficult to understand and that organic chemistry represents an important part of their future university education, are presented in Table 5.

Table 5. Students' perceptions toward organic chemistry

\begin{tabular}{|c|c|c|c|c|c|c|}
\hline \multirow{2}{*}{ Statement } & \multicolumn{2}{|c|}{ I completely agree } & \multicolumn{2}{|c|}{ I partially agree } & \multicolumn{2}{|c|}{ I do not agree } \\
\hline & $f$ & $\%$ & $f$ & $\%$ & $f$ & $\%$ \\
\hline $\begin{array}{l}\text { Organic chemistry is more difficult to learn than } \\
\text { general and inorganic chemistry }\end{array}$ & 116 & 71,17 & 15 & 9,20 & 32 & 19,63 \\
\hline Organic chemistry curriculum is too extensive & 134 & 82,21 & 16 & 9,82 & 13 & 7,97 \\
\hline $\begin{array}{l}\text { Organic chemistry academic content is difficult to } \\
\text { understand }\end{array}$ & 102 & 62,58 & 31 & 19,02 & 30 & 18,40 \\
\hline $\begin{array}{l}\text { Thorough knowledge of organic chemistry is important } \\
\text { for my future university education }\end{array}$ & 43 & 26,38 & 14 & 8,59 & 106 & 65,03 \\
\hline
\end{tabular}

As can be seen in Table 5, more than $70 \%$ of the students completely agreed with the statement that organic chemistry is more difficult to learn than general and inorganic chemistry. More than $80 \%$ of the students completely agreed with the statement that organic chemistry curriculum is too extensive, while more than $60 \%$ of them completely agreed with the statement that organic chemistry academic content is difficult to understand. Finally, $65 \%$ of the students did not agree with the statement that thorough knowledge of organic chemistry is important for their future university education.

Students' views on which organic chemistry topics are difficult to understand are presented in Table 6 (students were allowed to select more than one topic). 
Table 6. Organic chemistry topics which the students find difficult to understand

\begin{tabular}{lcc}
\hline Organic chemistry topics & $f$ & $\%$ \\
\hline The nomenclature of organic compounds & 67 & 41,10 \\
The structural representations of organic compounds & 80 & 49,08 \\
The physical properties of organic compounds & 81 & 49,69 \\
$\begin{array}{l}\text { The reaction mechanisms } \\
\begin{array}{l}\text { Determining which substance is the electrophile/nucleophile } \\
\text { in the given chemical reaction }\end{array}\end{array}$ & 132 & 80,98 \\
\hline
\end{tabular}

As can be seen from Table 6, more than $40 \%$ of the respondents reported difficulties with understanding of each of the enlisted topics. The reaction mechanisms turned out to be the most difficult to understand, while $60 \%$ of the students also reported difficulties with understanding which substance is the electrophile/ nucleophile in the given chemical reaction.

Table 7 presents the results of the students' evaluation of the quality of their organic chemistry knowledge, acquired during the current school year.

Table 7. Students' evaluation of the quality of their organic chemistry knowledge

\begin{tabular}{lcc}
\hline Option & $\boldsymbol{f}$ & $\%$ \\
\hline Poor & 65 & 39,88 \\
Quite satisfactory & 93 & 57,05 \\
Excellent & 5 & 3,07 \\
\hline
\end{tabular}

As can be seen from Table 7, nearly $40 \%$ of the students find that the quality of their organic chemistry knowledge acquired during the current school year is poor, while most of the other students find it to be quite satisfactory.

\section{RESULTS OF QUESTIONNAIRE 2}

Table 8 presents the students' perceptions concerning the effects of the application of context-based approach in organic chemistry teaching.

As can be seen from Table 8, 55\% of the students stated that the contextbased lesson about alcohols was more interesting than their typical organic chemistry lessons, while almost all of them stated that before this lesson, they were not aware of the various uses of these compounds in everyday life. More than $85 \%$ 
Table 8. The effects of the application of context-based approach in organic chemistry teaching

\begin{tabular}{|c|c|c|}
\hline Statement & $\begin{array}{l}\text { Number of students } \\
\text { who find this } \\
\text { statement to be true }\end{array}$ & $\begin{array}{l}\text { Percentage of } \\
\text { students who find this } \\
\text { statement to be true }\end{array}$ \\
\hline $\begin{array}{l}\text { The lesson about alcohols was more interesting than typical } \\
\text { organic chemistry lessons }\end{array}$ & 90 & 55,21 \\
\hline $\begin{array}{l}\text { Before attending the lesson about alcohols, I was unaware of } \\
\text { the extent to which these compounds are a part of our everyday } \\
\text { life }\end{array}$ & 158 & 96,93 \\
\hline $\begin{array}{l}\text { The lesson about alcohols inspired me to implement some of } \\
\text { the newly acquired knowledge about these compounds in my } \\
\text { everyday life }\end{array}$ & 85 & 52,15 \\
\hline $\begin{array}{l}\text { If more organic chemistry lessons resembled the lesson about } \\
\text { alcohols, the students would be more motivated to learn organic } \\
\text { chemistry }\end{array}$ & 147 & 90,18 \\
\hline $\begin{array}{l}\text { If more organic chemistry lessons resembled the lesson about } \\
\text { alcohols, the students would understand the content of organic } \\
\text { chemistry better }\end{array}$ & 28 & 17,18 \\
\hline $\begin{array}{l}\text { If more organic chemistry lessons resembled the lesson about } \\
\text { alcohols, the students would be better equipped to implement } \\
\text { their knowledge of organic chemistry in everyday life }\end{array}$ & 141 & 86,50 \\
\hline
\end{tabular}

of the students believe that a continued application of context-based approach in organic chemistry teaching would improve their motivation to learn organic chemistry, as well as their ability to apply organic chemistry knowledge in everyday life, with $52 \%$ of the students confirming that they already applied some of their newly acquired knowledge about alcohols in their everyday life. However, less than $20 \%$ of the students believe that a continued application of context-based approach in organic chemistry teaching would contribute to a better understanding of its academic content.

Finally, Table 9 presents the students' perceptions toward whether they would recommend to their teachers more frequent application of context-based approach in organic chemistry teaching.

Table 9. Students' perceptions toward whether they would recommend to their teachers more frequent application of context-based approach in organic chemistry teaching

\begin{tabular}{lcc}
\hline Option & $\boldsymbol{f}$ & $\%$ \\
\hline Yes & 96 & 58,90 \\
I don't know & 35 & 21,47 \\
No & 32 & 19,63 \\
\hline
\end{tabular}

As can be seen from Table 9, almost $60 \%$ of the students would recommend to their teachers more frequent application of context-based approach in organic chemistry teaching. 


\section{DISCUSSION}

The results of this research indicate that organic chemistry teaching in grammar school primarily consists of the teacher's presentation of academic content, according to the organic chemistry textbook. The new academic content is only occasionally linked with its application in everyday life, which is probably the reason why around $60 \%$ of the students completely or at least partially agreed with the statement that organic chemistry is an abstract subject, weakly connected to everyday life. This is also in accordance with the previous finding that students often perceive organic chemistry as abstract (O'Dwyer, Childs 2014: 988).

Despite the finding that teachers, at least occasionally, link new organic chemistry knowledge with their students' previously acquired chemistry knowledge and everyday life, around $63 \%$ of the students found organic chemistry to be difficult to understand, which is in accordance with the results of previous research (O'Dwyer, Childs 2014: 988). The students pointed out difficulties with understanding of the nomenclature and structural representations of organic compounds which were already noted (O’Dwyer, Childs 2014: 991), as well as problems with understanding of physical properties and concepts of electrophile and nucleophile, which have also been reported (Akkuzu, Uyulgan 2016: 48). Additionally, the students identified reaction mechanisms as the part of organic chemistry curriculum that is the most difficult to understand, which is in accordance with the results of previous research (O'Dwyer, Childs 2014: 990).

Overall, around $40 \%$ of the students found the quality of their organic chemistry knowledge to be poor, while the majority of the remaining students found it to be quite satisfying. Given that the relatively high percentage of students found the quality of their organic chemistry knowledge to be poor and that the majority of them found organic chemistry to be difficult to understand, perhaps it is not surprising that $65 \%$ of the students do not see organic chemistry as a major part of their future university education.

Almost all of the students stated that, before the context-based lesson about alcohols, they were not aware of the various uses of these compounds in everyday life, which confirms the finding that presentation of scientific content within various contexts of its application raises students' awareness of the relevance of that content in everyday life (Gilbert 2006: 962). More than 85\% of the students believe that if more of their organic chemistry lessons resembled the lesson about alcohols, they would be better equipped for the application of organic chemistry knowledge in everyday life. Moreover, 52\% of the students stated that they already applied some of the newly acquired knowledge about alcohols in their everyday life, which is in accordance with the finding that acquisition of knowledge in authentic contexts promotes the functionalization of that knowledge (Gilbert 2006: 965). The results of this research further show that $55 \%$ of the students perceived the lesson about alcohols to be more interesting than their typical organic chemistry lessons, 
while $90 \%$ of the students believe that if more organic chemistry lessons resembled the lesson about alcohols, they would be more motivated to learn organic chemistry. This finding confirms the results of previous research which indicate that presentation of scientific knowledge in authentic contexts enhances students' motivation to learn science (Gilbert 2006: 964). However, despite research evidence suggesting that presentation of new knowledge in contexts of its application promotes the conceptual understanding of that knowledge (Gutwill-Wise 2001: 687), only 17\% of the students believe that if more organic chemistry lessons resembled the lesson about alcohols, their understanding of organic chemistry would be improved. Nevertheless, nearly $60 \%$ of the students recommend to their teachers more frequent application of context-based approach in organic chemistry teaching.

\section{CONCLUSION}

This research was conducted in order to ascertain the way in which organic chemistry is typically taught in grammar school, grammar school students' perceptions toward organic chemistry and their perceptions concerning the potential of context-based teaching approach to facilitate organic chemistry learning. On the basis of the obtained results, it can be concluded that organic chemistry teaching in grammar school primarily consists of the teacher's presentation of academic content, which is only occasionally linked to everyday life and previously acquired chemistry knowledge. At the same time, students perceive organic chemistry as abstract, difficult to understand and more difficult to learn than general and inorganic chemistry. Around $40 \%$ of the students perceive the quality of their organic chemistry knowledge to be poor, while $65 \%$ of the students do not see organic chemistry as a major part of their future university education. On the other hand, students perceived the context-based organic chemistry lesson about alcohols to be more interesting than their typical organic chemistry lessons and expressed belief that such an approach to teaching could promote their motivation to learn organic chemistry and their ability to apply organic chemistry knowledge in everyday life. Although they do not believe that it could also promote their understanding of organic chemistry, nearly $60 \%$ of the students recommend to their teachers more frequent application of context-based approach in organic chemistry teaching.

Given that they clearly describe the way in which organic chemistry is taught in grammar school and the problems that the students face because of it, the results of this research could have important implications. First, grammar school teachers are signaled that they must make changes to their organic chemistry teaching practices. Furthermore, their students pointed out that the implementation of context-based approach could help to eradicate some of the key problems related to organic chemistry learning and, moreover, openly recommended a more frequent implementation of this teaching approach. Therefore, teachers are provided with an 
important indicator when it comes to the direction in which the necessary changes should be made.

To end with, the most important limitation of this research lies in the influence of the Hawthorne effect (Payne, Payne 2004: 108) which refers to the fact that, because of the awareness that their answers are being used in order to draw certain conclusions about themselves and their chemistry teachers, some of the views that the students expressed could have been altered compared to the views that would have been expressed under ordinary circumstances.

\section{REFERENCES}

Akkuzu, Uyulgan (2016): Nalan Akkuzu, Melis Arzu Uyulgan, An epistemological inquiry into organic chemistry education: exploration of undergraduate students' conceptual understanding of functional groups, Chemistry Education Research and Practice, 17(1), London: The Royal Society of Chemistry, 36-57.

Bennett, Lubben, Hogarth (2007): Judith Bennett, Fred Lubben, Sylvia Hogarth, Bringing science to life: A synthesis of the research evidence on the effects of context-based and STS approaches to science teaching, Science Education, 91(3), New York: American Chemical Society, 347-370.

Bretz (2001): Stacey Lowery Bretz, Novak's theory of education: human constructivism and meaningful learning, Journal of Chemical Education, 78(8), New York: American Chemical Society, 1107-1116.

Fensham (2009): Peter Fensham, Real world contexts in PISA science: implications for context-based science education, Journal of Research in Science Teaching, 46(8), Hoboken: John Wiley \& Sons, Inc., 884-896.

Gilbert (2006): John Gilbert, On the nature of "context" in chemical education, International Journal of Science Education, 28(9), Abingdon: Taylor \& Francis, 957-976.

Gutwill-Wise (2001): Joshua Gutwill-Wise, The impact of context-based learning in organic chemistry courses: An early evaluation, Journal of Chemical Education, 78(5), New York: American Chemical Society, 684-690.

Johnstone (2006): Alex Johnstone, Chemical education research in Glasgow in perspective, Chemistry Education Research and Practice, 7(2), London: The Royal Society of Chemistry, 49-63.

Kuhn, Muller (2014): Jochen Kuhn, Andreas Müller, Context-based science education by newspaper story problems: A study on motivation and learning effects, Perspectives in Science, 2(1-4), Amsterdam: Elsevier, 5-21.

Nicolau (2014): Kyriacos Nicolau, Organic synthesis: the art and science of replicating the molecules of living nature and creating others like them in the laboratory, Proceedings of the Royal Society A: Mathematical, Physical and Engineering Sciences, 470(2163), London: The Royal Society Publishing, 1-17.

Novak (2010): Joseph Novak, Learning, Creating, and Using Knowledge, New York: Taylor \& Francis Group.

O’Dwyer, Childs (2014): Anne O’Dwyer, Peter Childs, Organic Chemistry in Action! Developing an intervention program for introductory organic chemistry to improve 
learner's understanding, interest and attitudes, Journal of Chemical Education, 91(7), New York: American Chemical Society, 987-993.

Payne, Payne (2004): Geoff Payne, Judy Payne, Key concepts in social research, London: Sage Publication.

\section{Катарина Б. Путица}

Универзитет у Београду

Иновациони центар Хемијског факултета

\section{СТАВОВИ ГИМНАЗИЈАЛАЦА О ОРГАНСКОЈ ХЕМИЈИ И ПРИМЕНИ КОНТЕКСТУАЛНОГ ПРИСТУПА У НАСТАВИ ОРГАНСКЕ ХЕМИЈЕ}

Резиме: Поред тога што представља есенцијални део свакодневног живота, органска хемија има и огроман економски значај. Будући да гимназија представља основу за даље универзитетско образовање и професионални ангажман у овој области, унапређивање гимназијске наставе органске хемије је од великог значаја. Последично, циљеви овог истраживања су били утврђивање типичних карактеристика наставе органске хемије у гимназијама, као и утврђивање ставова гимназијалаца о органској хемији и потенцијалу контекстуалног приступа настави да олакша учење органске хемије. Истраживачки подаци су прикупљени посредством два упитника, које је попунило 163 ученика трећег разреда гимназије. Закључено је да се настава органске хемије у гимназији првенствено своди на наставниково излагање академских знања, која се само у ретким приликама повезују са свакодневним животом и претходно стеченим знањима из хемије. Истовремено, ученици сматрају да је органска хемија апстрактна, тешка за разумевање и тежа за учење од опште и неорганске хемије, док око $40 \%$ ученика сматра да је њихово знање органске хемије слабог квалитета. С друге стране, ученици сматрају да је настава заснована на примени контекстуалног приступа занимљивија од њихове уобичајене наставе органске хемије и истичу да би овакав приступ настави могао да допринесе већој мотивацији за учење органске хемије и бољој оспособљености ученика за примену знања из органске хемије у свакодневном животу. Иако нису убеђени да би овај приступ могао да допринесе и бољем разумевању градива органске хемије, скоро 60\% ученика препоручило је својим наставницима чешћу употребу контекстуалног приступа у настави органске хемије.

Кључне речи: органска хемија, контекстуални приступ настави, гимназијалци, упитници. 